\title{
Pemberdayaan Kelompok PKK Desa Ngembat Melaui Proses Transfer Keterampilan Membuat Stik Berbahan Dasar Petai Untuk Pengembangan Wirausaha Makanan Kekinian Sebagai Komoditas Khas Desa Ngembat
}

\author{
Ujang Rohman ${ }^{1}$, Sumardi ${ }^{2}$, Suharti. ${ }^{3}$, Hayati $^{4}$ \\ 1, 2, 3, 4 Program Studi Pendidikan Jasmani, Fakultas Keguruan dan Ilmu Pendidikan, \\ Universitas PGRI Adi Buana Surabaya \\ E-mail: ${ }^{1)}$ ujang_roh64@unipasby.ac.id.,
}

\begin{abstract}
ABSTRAK
Desa Ngembat merupakan salah satu desa yang berada di Wilayah Kecamatan Gondang Kabupaten Mojokerto. Potensi alam wilayah desa Ngembat salah satunya penghasil petai. Petai adalah potensi lokal yang cukup banyak dan belum dimanfaatkan dengan baik oleh masyarakat desa Ngembat. Fokus kegiatan PPM adalah mengenai petai yang diolah menjadi olahan pangan berupa stik berbahan dasar petai untuk memberdayakan masyarakat terutama ibu-ibu kelompok PKK desa Ngembat. Pemanfaatn petai menjadi olahan stik bertujuan untuk memanfaatkan sumber daya alam yang menjadi sumber pendapatan bagi masyarakat desa Ngembat dan untuk memberikan inspirasi serta motivasi masyarakat desa Ngembat mengenai peluang wirausaha stik berbahan dasar petai yang memiliki nilai jual. Metode pelaksanaan program PPM berdasarkan pengamatan di lapangan (observasi) dan wawancara (interview) meliputi penyuluhan (sosialisasi) dan praktek langsung. Dampak dari kegiatan PPM diperoleh manfaat peningkatan pengetahuan ibu-ibu PKK desa Ngembat tentang potensi lokal petai menjadi olahan pangan berbahan dasar petai dan terampil dalam membuat olahan pangan berupa stik berbahan dasar petai. Kesimpulan yang diperoleh bahwa program olahan kekinian berupa stik berbahan dasar petai mendapat respon positif dari ibu-ibu PKK dan hasil olahan stik tersebut direncanakan dipasarkan melalui program wirausaha desa sebagai komoditas khas oleh-oleh desa Ngembat.
\end{abstract}

Kata kunci : petai, pembuatan stik

\section{ABSTRACT}

Ngembat Village is one of the villages in the Gondang Sub-district Area of Mojokerto district. One of the natural potentials of the Ngembat village area is producing petai. Petai is quite a lot of local potential and has not been put to good use by the Ngembat village community. The focus of PPM activities is on petai which is processed into food processed in the form of sticks made from petai to empower the community, especially the women of the Ngembat village PKK group. Utilization of bananas to be processed sticks aims to utilize natural resources that are a source of income for Ngembat villagers and to inspire and motivate Ngembat villagers about the opportunity for banana-based stick entrepreneurs who have a sale value. The method of implementing the PPM program is based on field observations (observations) and interviews (interviews) including counseling (outreach) and direct practice. The impact of PPM activities is the benefit of increasing the knowledge of PKK Ngembat village women about the potential of local petai to be processed food made from petai and skilled in making food processed in the form of sticks made from petai. The conclusion that the current processed program in the form of sticks made from petai received a positive response from PKK mothers and the results of the processed sticks were planned to be marketed through the village entrepreneurship program as a typical commodity of Ngembat village souvenirs.

Keywords : petai, processed sticks 


\section{PENDAHULUAN}

Iklim yang cukup lembab di kawasan desa Ngembat sangat sesuai untuk pertumbuhan dan perkembangan pohon petai karena tektur tanahnya yang gembur dan liat yang dapat disesuaikan menjadikan pohon petai tumbuh subur di wilayah ini. Pohon petai merupakan tanaman tahunan yang dapat mencapai tinggi $20 \mathrm{~m}$ lebih dan kurang bercabang. Daunnya majemuk, tersusun sejajar. Bunga majemuk, tersusun dalam bongkol (khas mimosoidae). Tanaman petai dapat tumbuh pada tempat optimal $200-$ 800 dpl. Didaerah yang lebih rendah tanaman ini banyak diganggu oleh kumbang penggerek sedangkan didaerah yang lebih tinggi bijinya tidak dapat besar. Petai mulai berbuah pada umur 4-6 bulan dengan usia paling produktif 8-10 tahun. Iklim kawasan yang cukup lembab adalah sesuai untuk pertumbuhan pokok yang subur. Manfaat petai sebagai sumber energi dibanding apel, petai memiliki protein empat kali lebih banyak, karbohidrat dua kali lebih banyak, tiga kali lipat fosfor, lima kali lipat vitamin A dan zat besi, dan dua kali lipat jumlah vitamin dan mineral lainnya. Petai merupakan sumber energi yang baik, yaitu 142 kkal per 100 g biji. Petai mengandung tiga macam gula alami, yaitu sukrosa, fruktosa, dan glukosa yang dikombinasikan dengan serat. Kombinasi tersebut mampu memberikan dorongan tenaga instan, tetapi cukup lama dan cukup besar efeknya. Kandungan fosfor pada petai juga cukup baik, yaitu $115 \mathrm{mg}$ per $100 \mathrm{~g}$ biji. Fosfor merupakan mineral kedua terbanyak setelah kalsium. Kurang lebih satu persen berat tubuh kita terdiri dari fosfor. DNA dan RNA di dalam tubuh kita terdiri dari fosfor dalam bentuk fosfat, demikian juga membran sel yang membantu menjaga permeabilitas sel. (Verawaty, 2016). Petai berbentuk biji pipih memanjang serta bulat seperti almond dan memiliki aroma bau yang khas juga rasanya sedikit pahit. aroma bau yang menyengat setelah mengkonsumsi petai disebabkan adanya zat seperti axthionine, tentrathiane, trithiolane, pentathiopane, penthathiocane yang terkandung di dalam petai (Wonghirundecha, 2014). Walaupun aromanya demikian petai mengandung protein, lemak, karbohidrat, serat, energi, kalsium, kalium, zat besi, fosfor, mangan, magnesium, zinc, vitamin A, C dan tiamin serta memiliki manfaat dapat mengobati anemia atau kurang darah, sembelit atau susah buang air besar juga kaya akan mineral penting bagi tubuh, seperti kalisum, fosfor, magnesium, mangan, dan kalium. (Tami, 2010). Pohon dan buah petai dapat dilihat pada gambar berikut.
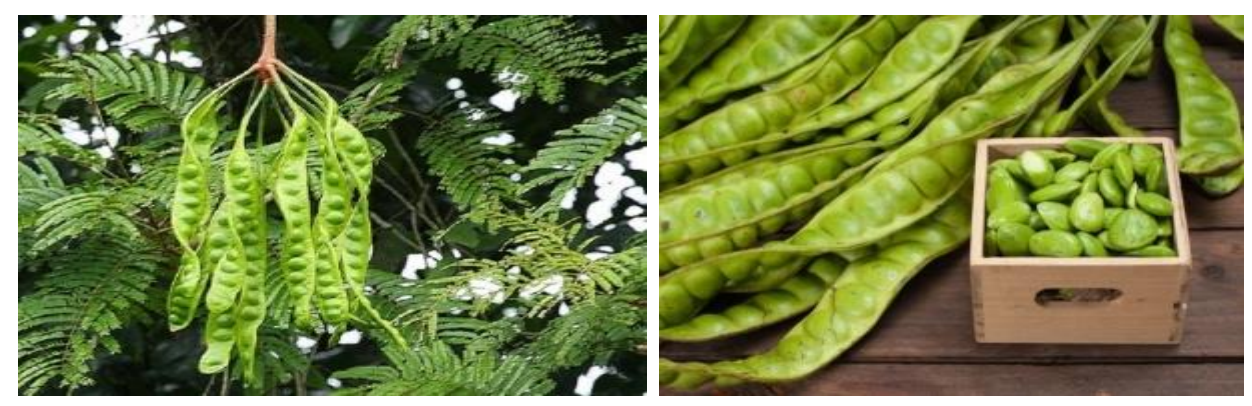

Gbr. 1 Pohon dan Buah Petai 
Banyaknya manfaat petai tersebut kurang dimengerti oleh masyarakat desa Ngembat. Masyarakat desa Ngembat memfaatkan petai hanya untuk dijual dan dikonsumsi terbatas sebagai lauk pauk pelengkap makan. Oleh karena itu agar dalam mengkonsumsi petai ini lebih variatif, Tim Program Pengabdian Masyarakat (PPM) mensosialisasikan dan memperkenalkan petai melalui penyuluhan dengan membuat varian olahan makanan berbahan dasar petai dalam bentuk olahan stik petai. Program olahan stik petai ini sebagai sarana untuk memperberdayakan masyarakat dalam meningkatkan nilai ekonominya. Masyarakat desa Ngembat agar memahami bagaimana manfaatnya olahan stik petai sebagai produk makan yang bergizi dan bernilai jual tinggi, maka perlu adanya pengetahuan dan keterampilan masyarakat untuk mengolah petai menjadi bahan olahan stik petai. Pemberdayaan masyarakat dalam memahami dan terampil membuat olahan makanan stik petai diharapkan masyarakat desa Ngembat tertarik untuk mencoba memproduksi sendiri olahan stik petai sehingga frospek ke depan akan muncul industri rumahan yang memproduksi olahan berbahan dasar petai bersama kelompok masyarakat desa Ngembat sebagai komoditas yang dijadikan oleh-oleh makanan kekinian yang khas desa Ngembat, kecamatan Gondang, kabupaten Mojokerto.

\section{METODE PELAKSANAAN}

Metode pelaksanaan program PPM berdasarkan pengamatan di lapangan (observasi) dan wawancara (interview). Menurut Sugiyono (2012), observasi sebagai teknik pengumpulan data yang mempunyai ciri yang spesifik karena tidak terbatas pada orang, tetapi juga objek-objek alam lainnya. Sedangkan wawancara digunakan sebagai teknik pengumpulan data apabila peneliti ingin melakukan studi pendahuluan untuk menemukan permasalahan yang harus diteliti (Sugiyono, 2012).

Observasi dan wawancara dilakukan mengenai pemanfaatan petai sebagai potensi lokal yang diolah menjadi bahan varian makanan berbentuk olahan stik petai. Teknik pengumpulan data dalam bentuk penyuluhan (sosialisasi) dan praktek langsung melalui pendampingan secara intensif kepada ibu-ibu PKK sampai memahami dan memiliki keterampilan membuat olahan stik petai berbahan dasar petai sehingga dapat menghasilkan produk kekinian berupa olahan stik petai untuk dijadikan komoditas oleholeh produk khas desa Ngembat, kecamatan Gondang, kabupaten Mojokerto.

Pelaksanaan pembuatan olahan stik petai dilaksanakan pada minggu ke 2 berkoordinasi dengan ibu-ibu PPK desa Ngembat yang berasal dari dusun Ngembat dan dusun Blentreng. Langkah-langkah untuk membuat produk olahan stik petai dari bahan dasar petai meliputi persiapan peralatan serta sarana prasarana yang dibutuhkan antara lain: kompor, gas, wajan, tempeh, sutil, talenan, pisau, sendok, baskom, sepet, saringan, blender. Sedangkan bahan dan cara-cara untuk membuat olahan stik petai berbahan dasar petai adalah bahan-bahan yang dibutuhkan antara lain: 100 gram margarin, 60 gram gula tepung, 1/4 sdt garam, 1 buah kuning telur, petai, 1/8 sdt esens, 150 gram tepung protein rendah, $1 \mathrm{sdk}$ baking powder.

Tata cara pembuatan stik petai: kocok margarin, gula tepung, dan garam selama 3 menit, tambahkan kuning telur, kocok sampai rata, masukkan petai yang sdh diblender 
EKOBIS ABDIMAS

Jurnal Pengabdian Masyarakat
Volume 1, Nomor 2, Desember, 2020

E - ISSN : 2721-9933

dan esens, kemudian aduk hingga merata serta beri air secukupnya. Tambahkan tepung terigu dan baking powder sambil diayak dan diaduk rata menyebar. Proses penyuluhan dan praktek membuat olahan stik petai berbahan dasar petai oleh tim PPM dapat di lihat pada gambar berikut.
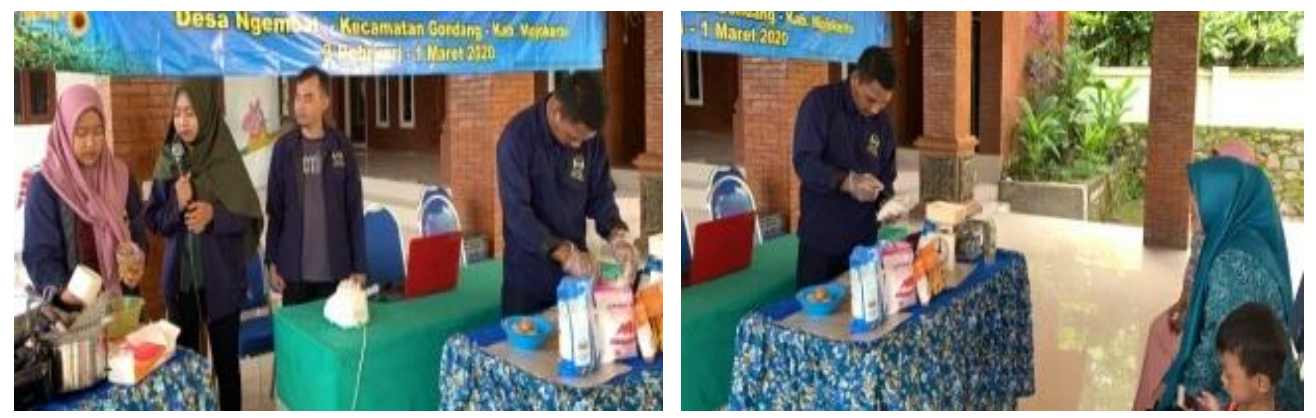

Gbr. 2 Praktek Tata Cara Membuat Stik Petai

Adonan olahan stik petai dicetak menngunakan Alat Cetak Stick, hasilnya letakkan diatas loyang yang sudah diolesi tipis margarin. Panaskan minyak dalam wajan, setelah panas masukkan mentega $1 \mathrm{sdm}$, ambil penggorengan, masukan adonan olahan stik petai ke dalam penggorengan serta aduk agar merata matengnya. Setelah minyaknya tidak berbuih dan stik petai berwarna kuning kecoklatan angkat dan tiriskan minyaknya sampai dingin dan stik petai siap dikonsumsi dan kemas. Tektur adonan stik petai setelah dicetak dan di goreng dapat dilihat pada gambar berikut.
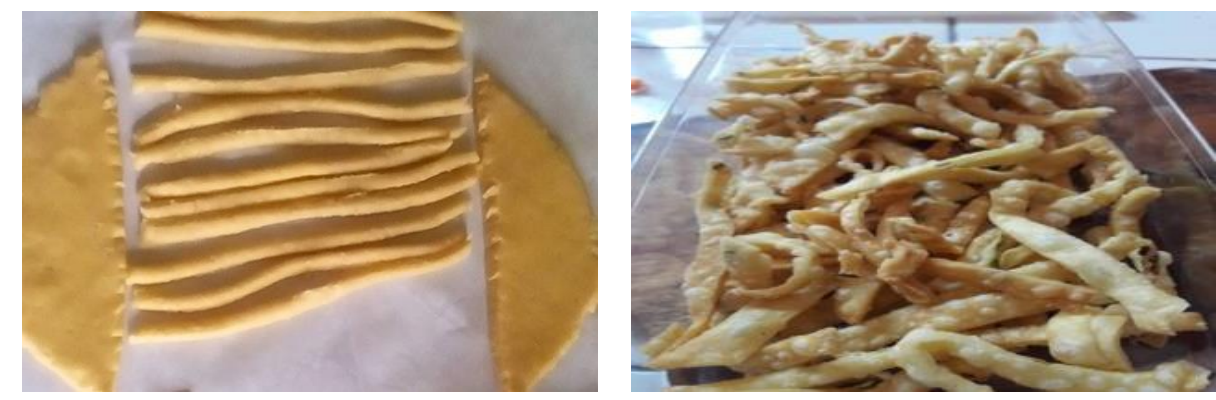

Gbr. 3 Adonan dan Hasil Olahan Stik Petai

\section{HASIL DAN PEMBAHASAN}

Petai atau pete (parkia speciosa hassk) merupakan tanaman tropika dari jenis polong-polongan (pabaceace) anak suku petai-petaian (mimosoide) berkembang luas di daerah sumatera dan jawa. Petai dikonsumsi secara langsung dalam keadaan segar atau direbus/dibakar untuk pelengkap makan. Tanaman petai (parkia speciosa hassk.) yang banyak dimanfaatkan oleh masyarakat Kamisah., Qodriyah., Jaarin., Othman (2013). Menurut Agnes dkk. (2013), petai memiliki efek hipoglikemik, aktivitas antioksidan, aktivitas antimikrobial, antiangiogenik, antitumor, dan antimutagenik. Tanaman petai 
(parkia speciosa hassk) mengandung alkaloid, saponin, terpenoid, fenolik, flavonoid, dan tanin (Ayu, 2014). kandungan senyawa polifenol, tanin, dan flavonoid pada tanaman petai mempunyai potensi antioksidan dan antibakteri.

Permasalahan yang ada mengenai potensi petai yang berkembang di desa Ngembat, selama ini hanya dijual dan dikonsumsi terbatas untuk pelengkap makan. Oleh karena itu dengan adanya program PPM membuat alternatif sebagai solusi agar petai dapat diolah menjadi berbagai varian makanan, salah satunya adalah olahan stik petai berbahan dasar petai. Program ini bertujuan untuk menciptakan produk olahan berbahan dasar petai. Berupa olahan stik petai melalui sosialisasi dan penyuluhan tata cara pengolahan makanan berbahan dasar petai. Dalam penyuluhan tersebut sekaligus dilakukan pelatihan atau praktek langsung bagiman petai di oftimalisasikan manfaatnya menjadi varian olahan stik petai berbahan dasar petai sehingga hasilnya akan memberdayakan masyarakat untuk berpartisipasi dan termotivasi mencoba membuat olahan petai menjadi olahan stik petai sebagai bahan makanan yang dikonsumsi keluarga dan juga sebagai altenatif untuk menambah sumber pengasilan masyarakat.

Kegunaan program PPM adalah bentuk pelayanan kepada masyarakat desa Ngembat sehingga setelah program ini selesai diharapkan:

1. Masyarakat lebih memahami pengetahuan tentang petai yang dapat dijadikan olahan makanan yang bernilai jual tinggi yang selama ini terbatas dikonsumsi sebagai pelengkap lauk pauk makan.

2. Masyarkat memiliki pengatahuan dan keterampilan dalam menciptakan varian olahan makanan dalam bentuk olahan stik petai yang bernilai jual tinggi

3. Pemahaman masyarakat tentang potensi ekonomi petai untuk dijadikan oleh-oleh makanan kekinian khas desa Ngembat yang dapat dimanfaatkannya untuk berwirausaha.

Kontribusi dari kegiatan PPM dalam bentuk pengabdian kepada masyarakat di desa Ngembat, kecamatan Gondang, kabupaten Mojokerto yang memiliki potensi alam sebagai penghasil petai namun karena terbatasnya pengetahuan masyarakat tentang pemanfaatan buah petai, maka luaran yang diharapkan dari program ini adalah:

1. Masyarakat mampu dan terampil dalam membuat olahan stik petai, karena petai mempunyai manfaat yang banyak tetapi masyarakat desa Ngembat kurang peka terhadap manfaat dan kegunaan petai.

2. Terciptanya peluang usaha atau lahan bisnis baru bagi masyarakat desa Ngembat sehingga dapat membatu perekomiannya, karena di lihat dari potensi ekonomi, olahan stik petai sangat berpotensi menjadi komoditas oleh-oleh makanan kekinian yang khas dari desa Ngmebat sebagai daerah pengunungan.

3. Melalui pembuatan olahan stik petai diharapkan dapat memberdayakan masyarakat dalam mengembangkan dirinya untuk ikut berperan aktif membantu perekomian desa.

Selain untuk menciptakan lapangan usaha dan tambahan penghasilan yang menguntungkan, produk olahan stik petai juga dapat lebih memperkenalkan desa Ngembat lebih luas lagi. Untuk masalah pemasaran, yang pertama promosi dapat 
dilakukan melalui media sosial. Media sosial akan sangat membantu agar masyarakat luas diluar desa Ngembat dengan mudah mengetahui produk khas olahan stik petai sebagai makanan kekinian dari desa Ngembat. Diharapkan produk ini mampu menjadi produk yang tidak hanya dikenal di desa Ngembat, melainkan di kenal seluruh Jawa Timur bahkan diluar Jawa Timu. Hasil produk olahan stik petai dalam kemasan dapat di lihat pada gambar berikut.

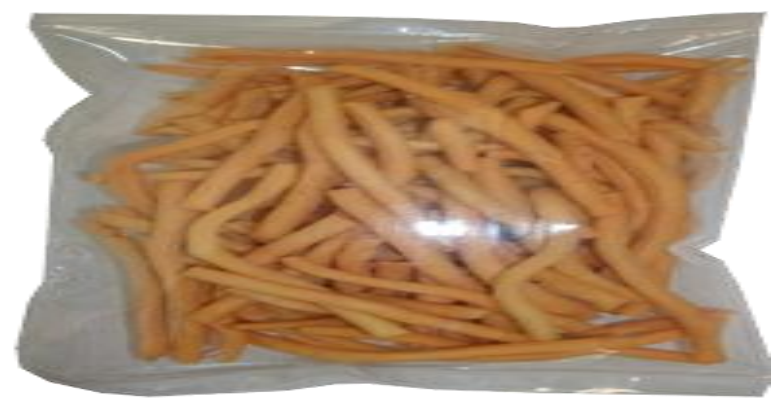

Gbr. 4 Kemasan Snack Stik Petai

Kemasan hasil olahan stik petai tersebut dikemas dengan kemasan yang kreatif dan menarik agar lebih dikenal dan mudah mempromosikannya sebagai komoditas makanan yang dijadikan oleh-oleh kekinian yang khas desa Ngembat, kecamatan Gondang Kabupaten Mojokerto.

\section{DAMPAK DAN MANFAAT KEGIATAN}

Petai merupakan salah satu potensi lokal hasil alam yang banyak di desa Ngembat, kecamatan Gondang kabupaten Mojokerto. Hasil panen petai belum terkelola dengan baik terutama dalam pengolahannya. Salah satu cara pengolaan petai yaitu dengan cara pengeolahan petai menjadi olahan makanan kekinian stik petai berbahan dasar petai.

Tujuan dari program ini adalah (1) Menciptakan produk olahan berbahan dasar petai, (2) Menciptakan varian produk olahan berbahan dasar petai dalam bentuk stik petai dengan kemasan yang inovatif, kreatif dan menarik sehingga bernilai jual tinggi, (3) Menjadikan olahan stik petai sebagai komoditas makanan kekikinian yang khas dari desa Ngembat. Untuk mencapai tujuan tersebut, tim PPM melaksanakan kegiatan sosialisasi dan praktek langsung (demo tata cara) membuat olahan berbahan dasar petai yang dilaksanakan setiap hari sabtu dan minggu selama tiga bulan (Desember 2019 s.d. Pebruari 2020) pada pukul 09.00 bertempat di dusun Ngembat, Desa Ngembat, Gondang, Mojokerto dengan sasaran kelompok ibu-ibu PKK di wilayah desa Ngembat. Selama kegiatan PPM telah berjalan dengan baik dimana tingkat partisipasi ibu-ibu PKK desa Ngembat selalu mengikuti petunjuk dan penjelasan tata cara membuat olahan stik petai serta dilanjutkan praktek langsung membuat produk olahan stik petai 
Indikator keberhasail PPM ditunjukkan selama mengikuti praktek langsung tata cara membuat olahan stik petai kemampuan ibu-ibu PKK dalam melaksanakan dari waktu ke waktu terus meningkat karena tim PPM mampu mengembangkan dan memjelaskan tata cara membuat olahan berbahan dasar petai berupa olahan stik petai. Hasil olahan stik petai ini merupakan suatu produk yang dapat dijadikan komoditas desa Ngembat karena produk olahan stik petai masih belum ada di wilayah Gondang dan sekitarnya sehingga diharapkan dapat dijadikan oleh-oleh khas kekinian dari desa Ngembat. Hasil yang telah dicapai pada kegiatan PPM adalah ibu-ibu PKK memiliki kemampuan dan keterampilan membuat olahan stik petai berbahan dasar petai. Selama kegiatan PPM telah berjalan dengan baik dimana tingkat partisipasi ibu-ibu PKK desa Ngembat selalu mengikuti sosialisasi demi sosialisasi dan praktek langsung membuat produk olahan stik petai berbahan dasar petai. Hasil produk olahan stik petai ini memberikan peluang bagi kelompok ibu-ibu PPK untuk berwirausaha karena bernilai jual yang menjanjikan untuk dijadikan komoditas oleh-oleh khas kekinian desa Ngembat.

Berdasarkan hal tersebut pengembangan kewirausahaan ini akan di monitor oleh tim PPM secara kontinyu dari tahun-ketahun. Oleh karena itu akan dilakukan refleksi sebagai umpan balik perencanaan tindakan dari tahun ke tahun berikutnya agar dapat dijadikan desa binaan sebagai sentra penghasil produk camilan (snack) stik petai yang berkesinambungan.

\section{SIMPULAN}

Pemanfaatan pengelolaan hasil alam buah petai berupa olahan stik petai telah berhasil memberdayakan masyarakat ke taraf hidup yang lebih baik dari sebelumnya karena pengolahan stik berbahan dasar petai memberikan peluang berwirausaha bagi masyarakat desa Ngembat karena bernilai jual yang menjanjikan untuk komoditas makanan kekinian. Hasil produk olahan stik petai ini memberikan peluang bagi kelompok ibu-ibu PPK dalam berwirausaha dan dapat dijadikan sebagai komoditas oleh-oleh khas kekinian desa Ngembat untuk pengembangannya.

\section{UCAPAN TERIMA KASIH}

Pelaksanaan kegiatan Pengabdian Kepada Masyarakat (PPM) berjalan lancar berkat adanya kerjasama antara Program Studi Pendidikan Jasmani. LP2M dengan perangkat Desa Ngembat, Kecamatan Gondang, Kabupaten Mojokerto. Oleh karena itu pada kesempatan ini kami sampaikan terimakasih kepada yang terhormat:

1. Ibu Dr. Sukarjati, M.Kes, Kepala LP2M Universitas PGRI Adi Buana Surabaya sebagai penyandang dana dalam kegiatan PPM ini.

2. Bapak Dr. Suhari, M.Si, Dekan Fakultas Keguruan dan Ilmu Pendidikan Universitas PGRI Adi Buana Surabaya

3. Bapak Sutrisno, Kepala Desa Ngembat yang telah memberikan ijin dan memfasilitasi kegiatan PPM di wilayah Desa Ngembat yang terdiri dari dusun Ngembat dan dusun Blentreng 
4. Teman-teman sejawat dosen Program Studi Pendidikan Jasmani atas kerjasama dalam pelaksanaan kegiatan PPM sampai selesai.

\section{DAFTAR PUSTAKA}

Agnes, Lois, O.W., Aning, A., Nani, A. 2013, Ekstrak Kulit Petai Sebagai Sumber Antioksidan dengan Metode Domestic Microwave Maceration, Jurnal Teknik Kimia Indonesia, 11(5) 237- 242

Anonim. 2017. Kandungan Gizi Petai. https://klinikgizi.com., kandungan-gizi-petaipete/. Diakses 26 februari 2020.

Ayu, D.P. 2014. Aktivitas Antibakteri Ekstrak Kulit Petai (Parkia Speciosa Hassk) Terhadap Bakteri Eschericia Coli dan Staphylococcus Aureus., Skripsi Tidak Dipublikasikan, Program Studi Biokimia, Fakultas Matematika dan Ilmu Pengetahuan Alam, Institut Pertanian Bogor, Indonesia.

Kamisah, Y., Qodriyah, M.S., Jaarin, K., Othman, F. 2013. Parkia Speciosa Hassk.: A Potential Phytomedicine, Jurnal Alternative Medicine, 6 (2) 1-3.

Pantastico E B. 2012. Fisiologi Pasca Panen, Penanganan, Pemanfaatan Buah-buahan dan Sayur-Sayuran Tropika daSubtropika (terjemahan). UGM Press. Yogyakarta.

Sugiyono, (2012). Metode Penelitian Pendidikan, Pendekatan Kuantitatif, Kualitatif dan R\&D, Cetakan Ke 14, Bandung: Alfabeta.

Soekresno, I.N.R.Pendit. 2004. Petunjuk Praktek Pramusaji Food dan Beverage Service. Buku Panduan Sekolah Pariwisata \& Perhotelan. Jakarta: PT. Gramedia Pustaka Utama.

Tami,H., 2010. Mengenal Lebih Jauh Tentang Petai,http://henithree. student.umm.ac.id., Diakses pada tanggal 25 Februari 2020.

Verawaty. 2016, Pengaruh Konsentrasi Ekstrak Etanol Kulit Petai dan Biji Petai (parkia speciosa hassk.) Terhadap Bakteri Eschericia Coli, Jurnal Akademi Farmasi Prayoga, 1 (1) 8-12.

Wonghirundecha, S., Benjakul, S., Sumpavapol, P. 2014. Total Phenolic Content, Antioxidant and AntimikrobiaActivities of Stink Bean (Parkia Speciosa Hassk.) Pod Extracts, Songklanakarin., Journal Sci Technol, 36 (3) 301-308 